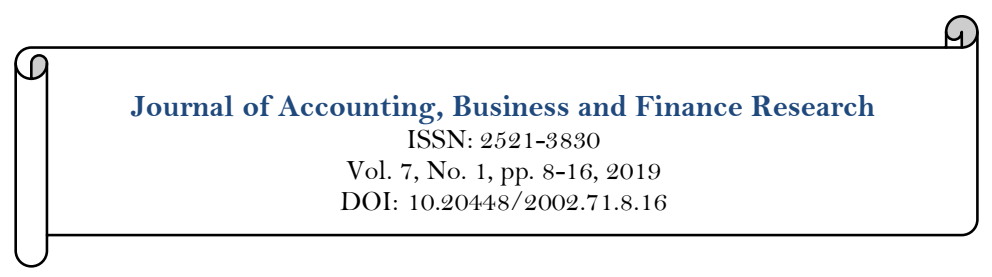

\title{
Do Corporate Social Responsibility and Corporate Governance Affect Tax Aggressiveness?
} Evidence from Indonesia

\author{
David H.M. Hasibuan ${ }^{1 *}$ \\ Khomsiyah $^{2}$ \\ 'Student of Accounting Doctoral Program, Trisakti University and STIE Kesatuan, Indonesia. \\ Email:hasibuan.david62@gmail.com \\ ${ }^{2}$ Lecturer of Accounting Doctoral Program Trisakti University, Indonesia.
}

\begin{tabular}{|c|c|}
\hline Abstract & \\
\hline $\begin{array}{l}\text { For businesses in Indonesia, corporate social responsibility (CSR) is still seen } \\
\text { as an additional burden that will incriminate the company. Based on the } \\
\text { observations of two companies that received awards for the CSR programs, } \\
\text { it seems that the company always received a Tax Underpayment Assessment } \\
\text { Letter (SKPB) from the Directorate General of Taxes for the period } 2014- \\
2017 . \text { This suggests that the burden of CSR incurred by the company exceeds } \\
\text { the limits set out in the provisions of Minister of Finance Regulation } \\
\text { Number (2O1 1). The indications that arise for these conditions are the } \\
\text { efforts made by the company to practice tax avoidance by posting CSR } \\
\text { expenses above the applicable provisions with the aim of reducing corporate's } \\
\text { income taxes. But the aggressive tax planning measures should be } \\
\text { minimized by implementation of good corporate governance (GCG). This } \\
\text { study aims to examine the effect of CSR and corporate governance (CG) on } \\
\text { corporate tax aggressiveness and the effect of CSR on tax aggressiveness } \\
\text { which is moderated by corporate governance. The objects of the research are } \\
\text { the financial statements of public companies listed on the Indonesia Stock } \\
\text { Exchange (IDX) with the observation period of } 2014 \text { - 2O17. The data are } \\
\text { analysed using multiple linear regression. The test results show that CSR } \\
\text { has a positive effect on tax aggressiveness, however corporate governance } \\
\text { does not affect tax aggressiveness. Furthermore, corporate governance has no } \\
\text { effect in moderating the effect of CSR on tax aggressiveness. }\end{array}$ & $\begin{array}{l}\text { Keywords: } \\
\text { CSR } \\
\text { Corporate governance } \\
\text { Tax aggressiveness } \\
\text { Avoidance. } \\
\text { Licensed: } \\
\text { This work is licensed under a } \\
\text { Creative Commons Attribution } 4.0 \\
\text { License. } \\
\text { Publisher: } \\
\text { Scientific Publishing Institute } \\
\text { Accepted: } 5 \text { August } 2019 \\
\text { Published: } 15 \text { August } 2019\end{array}$ \\
\hline
\end{tabular}

Funding: This study received no specific financial support.

Competing Interests: The authors declare that they have no competing interests.

\section{Research Background}

Since the enactment of the Act No. 40 of 2007 on Limited Liability Company, public companies in Indonesia tend to comply with the rules concerning CSR implementation. Based on the data gathered, almost all companies listed on the Indonesia Stock Exchange in 2014-2017 carried out CSR programs which were reported in the annual reports. Even among them there were companies that obtained CSR awards from CSR institutions or associations, both nationally and internationally, such as ASII and PTBA. ASII has been receiver of several awards, such as the 2015 Best Corporate Social Initiative and the 2014 ANTARA CSR Award. While PTBA recently also received the 2018 Padmamitra Award through a poverty alleviation program.

But interestingly, from the data we gathered, the two companies always received a Tax Underpayment Assessment Letter (SKPKB) in 2014-2017. SKPKB is a legal product issued by the Directorate General of Taxes as a result of a tax audit. SKPKB is issued in the event that the company has been examined and proven 
to report the tax incorrectly so that there is still a tax shortage that the company must pay. The total nominal SKPKB received by ASII and PTBA from 2014 to 2017 were Rp666 billion and Rp146 billion respectively.

To get a better confidence regarding this indication, we conducted a deeper look by pairing load CSR activities CSR award-winning company (in this case as the sample is ASII) with Minister of Finance Regulation (PMK) Number 76 / PMK.03 (2011). Based on the data that the we obtained, in 2014 ASII issued funds for CSR activities amounting to Rp529 billion (Astra International, 2019). While ASII's fiscal net income in 2013 was Rp5,405 billion. When referring to PMK 76/PMK.03/2011, the burden of CSR activities that could be deducted from gross income in 2014 should have been a maximum of Rp270 billion $(5 \% \mathrm{x}$ Rp5,405 billion). Thus, that the burden of ASII CSR activities in 2014 of Rp529 billion would be positively corrected by IDR259 billion (IDR529 billion - IDR270 billion). This observation further clarifies these indications that CSR is used as a means to practice tax avoidance by companies.

However, the decision to carry out aggressive tax planning does not rule out the possibility that it originates solely from management decisions. This is explained by Slemrod (2004) who states that the existence of agency problems can trigger management to carry out tax aggressiveness for management's personal interests. Thus, tax avoidance practices can be caused by agency problems that occur between the owner of the company as principal and management as agent. However, the agency problem, including the opportunistic behaviour of managers for tax avoidance, is supposed to be suppressed by the implementation of good corporate governance. Schön (2008) proves that good corporate governance should be used as a tool to combat tax avoidance. Moreover, the Financial Services Authority (OJK) has issued Regulation Number 21/POJK.04/2015 concerning the Implementation of the Guidelines for Public Company Governance which requires them to implement GCG and disclose it in the annual reports. Thus, a public company should have a good corporate governance mechanism in order to suppress the managers' opportunistic behaviour.

\section{Literature of Hypothesis Review and Development}

Lanis and Richardson (2012) suggest that CSR is one of the keys to achieving success and sustainability so that the company should have CSR programs. By implementing CSR, the company will gain legitimacy in the surrounding environment and can also enhance its reputation as a company that pays attention to its social responsibility.

The legitimacy theory also applies to the practice of tax avoidance. In a social view, companies that deliberately avoid taxation to reduce their taxes will be seen as illegitimate social contracts (Avi-Yonah, 2008). Lanis and Richardson (2012) show that tax avoidance is considered an act that has no social responsibility because it can adversely affect the economy of the local community. Therefore, by taking a passive attitude towards taxes, the company will gain legitimacy in the community and can choose the sustainability of its business activities in the community. In other words, CSR and taxes are complementary (Mao, 2019).

Minor and Morgan (2011) state that companies that have a high reputation tend to avoid serious problems related to political, regulatory, and social violations. Minor and Morgan (2011) add that CSR can function like insurance that can help companies in reducing sanctions when they are involved in a negative case. The practice of tax avoidance by utilizing CSR can also be explained using a perspective of risk management strategies (Mao, 2019). In this perspective, companies tend to comply with CSR activities. CSR programs are used by the company as a tool to cover up the tax avoidance practices it does (Mao, 2019). In other words, the relationship between CSR and taxes is substitute or CSR has a positive influence on the level of tax aggressiveness. Whereas Roman and Grant (2014) conducted research related to the effect of CSR and corporate tax aggressiveness. Both found that CSR performance is inversely proportional to tax avoidance efforts. Based on the description above, the first hypothesis proposed from this study is:

$H_{1}$ : CSR has a positive effect on tax aggressiveness.

The implementation of good corporate governance is seen as able to reduce agency problems and improve company performance (Sheikh \& Rees, 1995). The implementation of good corporate governance encourages management to manage the company more efficiently and implement policies that are suitable for the company' interests.

The results of research conducted by Desai and Dharmapala (2006) show that tax planning policies are influenced by the implementation of corporate governance. The research conducted by Irawan and Farahmita (2013) found similar results; namely there is a significant negative relationship between corporate governance and tax aggressiveness. Another study conducted by Sari (2010) found that corporate governance had a negative effect that was not significant for tax aggressiveness. Based on the description above, the second hypothesis proposed from this study is:

$H_{2}$ : Corporate governance has an effect on tax aggressiveness.

CSR activities carried out by companies have an important role in the sustainability of the company (Lanis \& Richardson, 2012). CSR can be reflected in CSR reporting which involves disclosing information about economic, social and environmental activities, as well as corporate governance performance (Hung, Shi, \& Wang, 2013). To maintain the continuity of the company in the long-term, especially with regard to social and 
environmental issues, it is necessary to converge between CSR and corporate governance for better management (Uwuigbe, Egbide, \& Ayokunle, 2011). Thus, the company is also expected to be responsible for the stakeholders, although the current view still assumes that the company's main responsibility is creating value for the shareholders (Margolis, Elfenbein, \& Walsh, 2007). According to Handajani, Subroto, and Saraswati (2014) the convergence between corporate governance and CSR does not only reduce agency costs, it will also create stakeholder value so that it has a positive impact on the company's sustainability in the longterm. Handajani et al. (2014) added, if corporate governance is still oriented to the short-term, namely to address agency problems without accommodating stakeholder interests and long-term sustainability issues corporate governance will not lead to corporate's CSR improvement. Handajani et al. (2014) found that corporate governance has a significant positive effect on CSR disclosures. They concluded that there was an increase in the convergence between corporate governance and CSR. Based on the description above the third hypothesis proposed from this study is:

$H_{s}$ : Corporate governance moderates the relationship of CSR to tax aggressiveness.

\section{Research Methods}

The object of the research is secondary data obtained from the financial statements and annual reports of these companies. The data will be selected using certain criteria to meet the needs of the research variables. That is why a purposive sampling technique will be used to obtain the research samples as can be seen in Table 1. The criteria excluded in the selection of samples are as follows:

1. The company did not produce the financial statements nor complete the annual reports for the period 2014-2017.

2. The company presented the financial statements other than in Rupiah.

3. The company was listed and/or delisted for the period 2014-2017.

4. The company did not disclose SKPKB in financial reports and/or the annual reports.

The type of data used is secondary data which are a collection of data collected by individuals or entities for other purposes, not by researchers who conduct the research (Sekaran, 2003). The data under study are the financial statements and annual reports from the companies under study. The data are obtained from the IDX official website (www.idx.co.id), the official website of the company under study, and other relevant sources.

\begin{tabular}{c|l|c}
\multicolumn{2}{c}{ Table-1. The results of samples selection using purposive sampling. } & Total \\
\hline No. & Criteria & 583 \\
\hline 1 & Number of companies registered in a row during the 2014 to 2017 period & $(46)$ \\
\hline 2 & Number of companies that did not have complete data for the period 2014-2017 & $(83)$ \\
\hline 3 & Number of companies that did not use Rupiah in their financial statements & $(403)$ \\
\hline 4 & $\begin{array}{l}\text { Number of companies that did not disclose underpayment tax assessment } \\
\text { letters in successive financial statements during the period 2014 to 2017 }\end{array}$ & 51 \\
\hline 5 & Number of companies that meet the criteria & 4 \\
\hline 6 & Number of years of observation & 204 \\
\hline 7 & Number of research samples
\end{tabular}

\subsection{The Definition of Operational Variables}

This study uses three types of variables, namely the independent variable, the dependent variable, and control variables. The dependent variable is a variable that is affected by an independent variable (Sugiyono, 2016).

\subsubsection{Dependent Variables}

The dependent variable in this study is tax aggressiveness (TAG). Tax aggressiveness in this study is defined as manipulation activities that aim to reduce taxable income through tax planning, either done legally or in breach of the regulations. This definition is in line with Frank, Lynch, and Rego (2009) and Chen, Chen, Cheng, and Shevlin (2010).

This study uses the underpayment tax assessment (SKPKB) received to identify tax aggressiveness. In this case, the SKPKB used is the SKPKB which has obtained final legal provisions, both before and after passing the process of objections and appeals (Geraldina, 2013). In this study, the level of tax aggressiveness is proxies using the principal amount of tax plus sanctions contained in the SKPKB which are scaled by total sales (Geraldina, 2013).

\subsubsection{Independent Variables}

The independent variables in this study are corporate social responsibility (CSR) as well as corporate governance $(\mathrm{CG})$. Both variables can be explained as follows: 


\subsubsection{Corporate Social Responsibility (CSR)}

CSR variables are proxies using CSR disclosures contained in the company's annual report. To determine the levels of CSR disclosures, we use the CSR disclosures index based on the GRI 2016 Sustainability Reporting Standards made by the Global Reporting Initiative (2016). In these standards, there are three categories of CSR disclosures, namely economic, environmental, and social categories. Furthermore, the three categories give detail into 77 items of CSR disclosures that are used as indicators of CSR disclosures. In this study, CSR is measured by using the number of CSR disclosures divided by the total CSR disclosure items whose value ranges between $0-1$. If the closer the value to 1 , means the CSR implemented by the company is better. The calculation formula for this variable is as follows:

If the closer the value to 1 , means the CSR implemented by the company is better

$$
C S R=\frac{\text { Total CSR Disclocure }}{\text { Total CSR Disclosure Item }}
$$

\subsubsection{Corporate Governance}

The Corporate Governance (CG) variable is measured by calculating indices based on the 2015 G20/OECD Corporate Governance Principles. These guidelines consist of five main measurement dimensions, namely the rights of shareholders, the equitable treatment of shareholders, the role of stakeholders, disclosure and transparency, and the roles of the board of directors. The five dimensions are then derived into several disclosure items that will be used to calculate corporate governance indexes (Cheung et al., 2014). CG measurements in this study use a number of disclosed corporate governance items divided by total corporate governance disclosure items. The measurement results range from $0-1$. If the score near to 1 , the better corporate governance implementation. The calculation formula for this variable is as follows:

$$
C G=\frac{\text { Total CG Disclosure }}{\text { Total CG Disclosure Item }}
$$

\subsubsection{Control Variables}

The control variables in this study are profitability (ROA), company size (SIZE), and leverage (LEV). Profitability, according to Gupta and Newberry (1997) has an effect on tax aggressiveness. The profitability variable in this study is proxied using ROA (profit before tax divided by total assets). Furthermore, the company size variable is used to control the effects of economies of scale. According to the Political Cost Theory proposed by Watts and Zimmerman, managers from large companies are more motivated to report smaller profits in their financial statements to avoid large tax obligations (Godfrey, Hodgson, Tarca, Hamilton, \& Holmes, 2010). The size of the company in this study is measured by natural logarithms (ln) of total assets (Lanis \& Richardson, 2012). Furthermore, the leverage variable is used to control the effect of debt on corporate tax reduction efforts. Leverage is the proportion of long-term debt to total assets. Leverage has a positive effect on tax aggressiveness because the interest expense borne by the company can reduce corporate tax (Lanis \& Richardson, 2012).

\subsubsection{Research Model}

We build a research model based on previous researches. This model is used in previous studies that examined the effect of CSR and corporate governance on tax aggressiveness (Irawan \& Farahmita, 2013; Pradipta \& Supriyadi, 2015; Roman \& Grant, 2014; Sari, 2010; Tjondro, Widuri, \& Katopo, 2016). Some control variables used, namely profitability, company size, and leverage, are based on previous researches which found that these variables influence tax aggressiveness (Pradipta \& Supriyadi, 2015; Roman \& Grant, 2014; Sari, 2010). The research model that will be used is as follows:

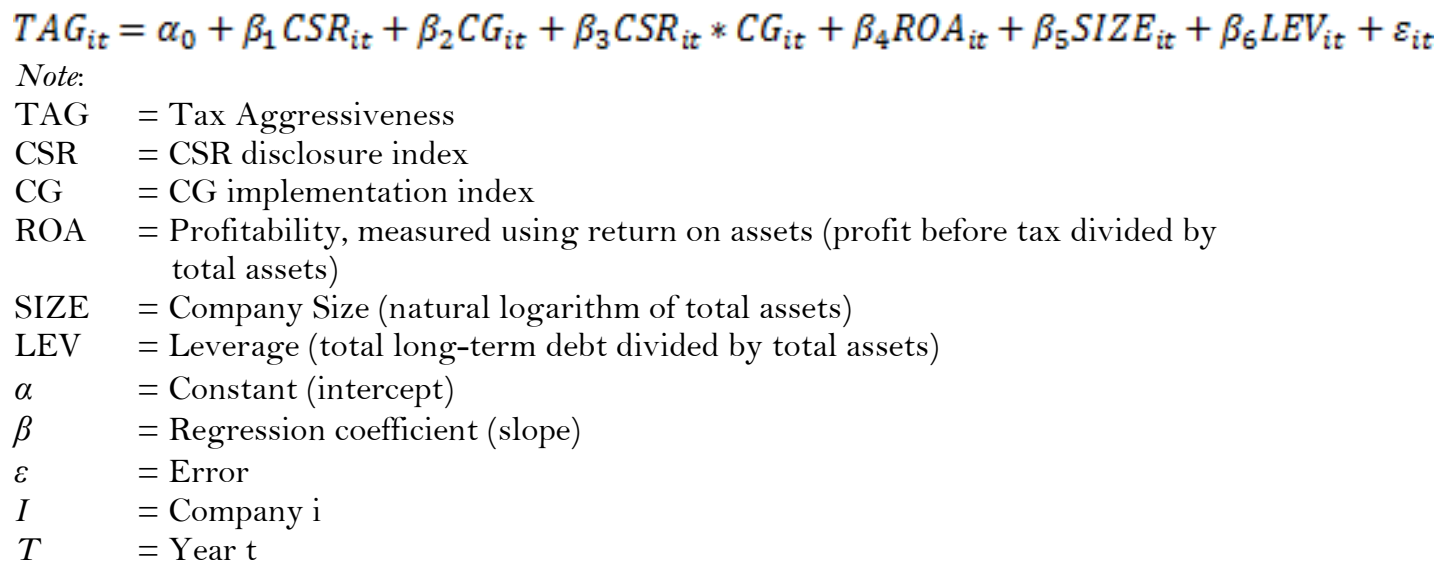


In this study, the significance level used is $5 \%$. We will be using STATA 14software for statistical testing because it is most suitable for the conditions of the data collected.

\section{Results}

\subsection{Descriptive Statistics Analysis}

The descriptive method provides a general overview of the condition of the data used in the study without intending to make conclusions from these data. The results of the descriptive statistics in this study are shown in Table 2 .

Table-2. The descriptive statistics of the research variables.

\begin{tabular}{c|c|c|c|c|c|c}
\hline Variable & N & Mean & Median & Min & Max & Std. Dev \\
\hline TAG & 204 & 0.00454 & 0,00136 & 0.00000 & 0.05213 & 0.00831 \\
\hline CSR & 204 & 0.25719 & 0.24675 & 0.12987 & 0.54545 & 0.07211 \\
\hline CG & 204 & 0.79382 & 0.79592 & 0.57143 & 0.97959 & 0.07862 \\
\hline ROA & 204 & 0.06766 & 0.05434 & $-0,54744$ & 0.48337 & 0.10449 \\
\hline SIZE & 204 & 29,8343 & 29,7312 & 26,1882 & 33,3201 & 1,57826 \\
\hline LEV & 204 & 0.51969 & 0.48379 & 0.12197 & 1,92278 & 0.25720 \\
\hline
\end{tabular}

A more detailed descriptive analysis of the CG variables is shown in Table 3 where it is known that there are two aspects which are still relatively low, namely equitable treatment for Shareholders (CG_B) and The Role of Stakeholders (CG_C). Both of these aspects have a mean value of 0.60348 and 0.66667 , respectively. These show that during the observation period, the companies under study have an average implementation of the equitable treatment for shareholders $\left(\mathrm{CG}_{-} \mathrm{B}\right)$ and the role of stakeholders $\left(\mathrm{CG}_{-} \mathrm{C}\right)$ aspects that have not been good.

\begin{tabular}{c|c|c|c|c|c}
\multicolumn{7}{c}{ Table-3. The descriptive statistics of CG variable components. } \\
\hline Variable & N & Mean & Min & Max & Std. Dev \\
\hline CG_A & 204 & 0.82046 & 0,00136 & 0.12500 & 0.16228 \\
\hline CG_B & 204 & 0.60348 & 0.24675 & 0.33333 & 0.14960 \\
\hline CG_C & 204 & 0.66667 & 0.79592 & 0.50000 & 0.18347 \\
\hline CG_D & 204 & 0.94321 & 0.05434 & 0.75000 & 0.05108 \\
\hline CG_E & 204 & 0.78462 & 0.93750 & 0.56250 & 0.08689 \\
\hline
\end{tabular}

\subsection{Regression Model}

There are three possible model approaches that can be used to perform panel data regression, namely the common effect model (OLS), the fixed-effect model, and the random effect model (Gujarati \& Porter, 2009). Of the three approaches, a regression model approach will be chosen that best fits the data through analysis of data processing. We obtain consistent results that the more appropriate regression model is the fixed effect model.

\subsection{Classic Assumption Test}

The normality test is done to find out whether the residual variables are normally distributed (Ghozali, 2016). The normality test conducted in this study uses the normal probability plot graph analysis. Graph analysis in a normality test with a normal probability plot is considered more reliable because it compares the cumulative distribution of the normal distribution.

The multicollinearity test aims to find out whether in the regression model there is a fairly high correlation between the independent variables (Ghozali, 2016). Multicollinearity testing is done by looking at the value of variance influence factor (VIF). VIF values can show the effect of each independent variable on other independent variables. If the VIF value is more than 10 (VIF $>10$ ), it can be said that there is a multicollinearity problem between independent variables (Ghozali \& Ratmono, 2013). The results of testing VIF values on all independent variables have been below 10 (VIF $<10$ ). Thus, it can be concluded that the regression model is free of multicollinearity problems.

Heteroscedasticity test aims to test whether the regression model has a difference in variance at each residual (Ghozali, 2016). Heteroscedasticity might cause the estimator to not be BLUE (Best Linear Unbiased Estimator) and efficient so that the $\mathrm{t}$ value of statistics and $\mathrm{F}$ count are not represented (Ghozali \& Ratmono, 2013). Heteroscedasticity test refers to the value of $\left[\mathrm{Prob}>\mathrm{Chi}^{2}\right]$ and alpha value. $\mathrm{N}$ values $\left[\mathrm{Prob}^{2} \mathrm{Chi}^{2}\right]$ generated amount to 0.0000 or less than the value of alpha $(0.05)$ so that $\mathrm{H}_{0}$ is rejected and $\mathrm{H}_{1}$ is accepted. Thus, there is a heteroscedasticity problem in panel data. However, referring to the research of Hoechle (2007) the problem of heteroscedasticity can be overcome by using heteroscedasticity-consistent standard errors or "White" standard errors. 
Autocorrelation test is testing that aims to find out whether in the regression model there is a correlation between residual errors in period $t$ with interfering errors in period $t-1$ (Ghozali, 2016). The problem of autocorrelation occurs when there is a correlation between disturbing errors in period t with interfering errors in period t-1. The autocorrelation test in this study is carried out using the Woolridge Test for Autocorrelation in Panel Data method in the STATA 14 software.

If the generated value of [Prob> F] is greater than alpha (0.05), then $\mathrm{H}_{0}$ is accepted, which means there is no problem of autocorrelation in the panel data. Conversely, if the [Prob $>\mathrm{F}]$ produced is smaller than alpha (0.05), then $\mathrm{H}_{0}$ is rejected and $\mathrm{H}_{1}$ is accepted, which means there is a problem of autocorrelation in the panel data. The generated value of $[$ Prob $>\mathrm{F}]$ is equal to 0.4989 or greater than the value of alpha (0.05), so that $\mathrm{H}_{0}$ is accepted or there is not a problem of autocorrelation in the panel data.

\subsection{Regression Results}

Hypothesis testing is done to prove the hypotheses that have been developed based on the relevant theories and previous studies on the topic of research. The feasibility test of the regression model (goodness of fit) will be carried out first before testing the research hypothesis. The feasibility test of a regression model will be comprised of a test coefficient of determination $\left(\mathrm{R}^{2}\right)$, the simultaneous significance test (statistical test $\mathrm{F})$, and the individual parameter significance test ( $\mathrm{t}$ statistical test).

\begin{tabular}{c|c|c|c|c|c|c}
\multicolumn{7}{c}{ Table-4. The statistical results of t test. } \\
\hline TAG & Coef. & Robust Std. Err. & $\mathbf{z}$ & $\mathbf{P}>|\mathbf{z}|$ & \multicolumn{1}{c}{ (95\% Conf. Interval) } \\
\hline cent_CSR & .070896 & .012981 & 5.46 & 0,000 & .045453 & .0963383 \\
\hline cent_CG & -.00229 & .004695 & -0.49 & 0.625 & -.0114962 & .0069076 \\
\hline cent_CSRxCG & -.04868 & .212151 & -0.23 & 0.818 & -.4644929 & .3671246 \\
\hline ROA & -.01406 & .006679 & -2.11 & 0.035 & -.027153 & -.0009721 \\
\hline SIZE & -.00156 & .000382 & -4.08 & 0,000 & -.0023075 & -.0008099 \\
\hline LEV & -.00139 & .002561 & -0.54 & 0.588 & -.0064062 & .0036309 \\
\hline cons & .052648 & .012102 & 4.35 & 0,000 & .0289287 & .763666 \\
\hline
\end{tabular}

Source: The results of data processing using STATA 14

Based on the results of the statistical t test in Table 4, it can be seen that the variables cent_CSR, ROA, and SIZE have values of $[\mathrm{P}>|\mathrm{z}|]$ smaller than the alpha value (0.05). This means that $\mathrm{H}_{0}$ on the three variables is rejected or it means the three variables individually are a significant explanatory on the dependent variable. The cent_CSR variable has a positive coefficient. Meanwhile, the variables ROA and SIZE have negative coefficients. The variables that have $[\mathrm{P}>|\mathrm{z}|]$ greater than alpha (0.05) are cent_CG, cent_CSRxCG, and LEV. Thus, $\mathrm{H}_{0}$ for these three variables are accepted or it means these three variables on an individual basis are not the significant explanations on the dependent variable.

\subsubsection{Hypothesis Testing Results}

This study proposes three working hypotheses. The decision to accept or reject the working hypothesis is based on the value of $[\mathrm{P}>|\mathrm{z}|]$ from the results of the statistical t test. The results of hypothesis testing are as follows:

i. CSR affects tax aggressiveness.

The first working hypothesis $\left(\mathrm{H}_{1}\right)$ predicts that corporate social responsibility has an effect on tax aggressiveness. The significance of the cent_CSR variable against TAG is determined by the value $[\mathrm{P}>|\mathrm{z}|]$ of the variable cent_CSR in the $\mathrm{t}$ test. If the value of $[\mathrm{P}>|\mathrm{z}|]$ is greater than the alpha value (0.05), then the hypothesis $\mathrm{H}_{1}$ will be rejected. And vice versa, if the value of $[\mathrm{P}>|\mathrm{z}|]$ is smaller than the alpha value (0.05), then the hypothesis $\mathrm{H}_{1}$ will be accepted. CSR has a significant influence on corporate tax aggressiveness. In addition, the regression coefficients have a positive direction which indicates that CSR has a positive effect on corporate tax aggressiveness.

ii. Corporate governance has an effect on tax aggressiveness.

The second working hypothesis $\left(\mathrm{H}_{2}\right)$ predicts that corporate governance has an effect on tax aggressiveness. The significance of the variable cent_CG to TAG is determined by the value $[\mathrm{P}>\mid \mathrm{z}$ $1]$ of the variable cent_CG in the $t$ test. Based on the results of the $t$ test in Figure 1, it is known that the value of $[\mathrm{P}>|\mathrm{z}|]$ of the independent variable cent_CG is 0.625 or it exceeds the alpha value (0.05). In other words, corporate governance does not have a significant effect on corporate tax aggressiveness. In addition, the coefficient of regression results has a negative direction which indicates that corporate governance has a negative effect on corporate tax aggressiveness. On this basis, the results of this test direct the decision to reject $\mathrm{H}_{2}$ because the value of $[\mathrm{P}>|\mathrm{z}|]$ is greater than the alpha value $(0.05)$.

iii. Corporate governance moderates the relationship of CSR to tax aggressiveness. 
The third working hypothesis $\left(\mathrm{H}_{3}\right)$ predicts that corporate governance will moderate (strengthen or weaken) the relationship of CSR to tax aggressiveness. This hypothesis suggests that the level of corporate governance implementation that is carried out by the company can affect the relationship of CSR to corporate tax aggressiveness. The decision to accept $\mathrm{H}_{3}$ is based on the value of $[\mathrm{P}>|\mathrm{z}|]$ smaller than the alpha value (0.05). Based on the results of the test in Figure 1, it is known that the value of $[\mathrm{P}>|\mathrm{z}|]$ of the independent variable cent_CSRxCG is 0.818 or it exceeds the alpha value (0.05). In other words, corporate governance does not moderate the relationship of CSR to corporate tax aggressiveness. On this basis, the results of this test direct the decision to reject $\mathrm{H}_{3}$.

\subsubsection{Discussion}

i. The Impacts of Corporate Social Responsibility (CSR) on Tax Aggressiveness

Based on the results of the regression test, this research shows that CSR variables have a significant effect on the dependent variable. Thus, the working hypothesis $\mathrm{H}_{1}$ in this study is accepted. In addition, the CSR variable coefficient is positive, which means that the higher the level of CSR performance carried out by the company, the higher the level of corporate tax aggressiveness. The results of this study are consistent with the research conducted by Maraya and Yendrawati (2016) and Mao (2019). Maraya and Yendrawati (2016) show that the companies seem to have double obligations to budget the funds for both CSR and taxation activities. Thus, the companies would tend to be more aggressive in tax planning. Whereas Mao (2019) found that the companies involved in CSR programs have a higher level of tax aggressiveness compared to the companies that are not involved in CSR. Mao (2019) argues that companies involved in CSR activities have the motive to hide the practice of tax avoidance because the companies' involvement in CSR can reduce the risk of tax audits by the tax authority.

ii. The impacts of Corporate Governance (CG) on Tax Aggressiveness

Based on the results of the regression test, we find that the CG variable has a negative relationship, but the effect is not significant on the dependent variable. The results of this study are not in accordance with the working hypothesis $\mathrm{H}_{2}$. The results of this study implicitly indicate that the implementation of corporate governance in public companies in Indonesia is still not effective in reducing agency problems, one of which is manager's opportunistic behaviour in the form of aggressive tax planning. The results of this study are also not in line with the previous studies which stated that corporate governance has an effect on tax aggressiveness. The research conducted by Irawan and Farahmita (2013) found that the practice of corporate governance can encourage managers to be more careful in conducting tax planning so that the better the implementation of corporate governance, the least aggressive tax planning is done. However, the results of this study are in line with the research conducted by Sari (2010) which found that corporate governance did not affect tax aggressiveness. Furthermore, Sari (2010) explained that public companies tend to be limited in fulfilling IDX regulations without actually implementing good corporate governance in managing their business activities. The results of this study can be explained by several things. Firstly, good corporate governance has not been fully implemented by all public companies in Indonesia. The obligation to implement good corporate governance in Indonesia began to be encouraged since the issuance of the Financial Services Authority Regulation (2015) concerning the Implementation of Public Company Governance Guidelines. The regulation has been in effect since the financial year 2016. However, from the data that we obtained, not all companies did implement this rule in 2016 and 2017. Secondly, there are several aspects of corporate governance that are still low in implementation. Based on the data in this study, the sample companies in this research get an average score in the aspect of equitable treatment of shareholders (Section B - OECD Corporate Governance) and the role of stakeholders (Section C - OECD Corporate Governance), which are only 0.6034 and 0.6667 respectively. The low implementation of corporate governance in the aspect of equitable treatment of shareholders indicates that each shareholder gets unequal treatment within the company. This may cause the minority shareholders will not not have sufficient influence in determining the direction of company policy. Meanwhile the low implementation of the role of stakeholders indicates that the company does not really care about the role and interests of stakeholders such as related to the welfare and security of its employees, the role of key stakeholders, information disclosures, and public communications. These practices may result in the supervising function by stakeholders does not go well so that the management, even the controlling shareholders, can hide the policies that may be negative.

iii. The Impacts of Corporate Governance (CG) on the Relationship between Corporate Social Responsibility (CSR) and Tax Aggressiveness

The latest views regarding corporate governance have begun to accommodate sustainability issues and not only focus on agency issues that are focusing on the interests of shareholders and management. On the issue of sustainability, the interests of stakeholder are what determine the company's sustainability in the long-run. This new view extends corporate governance perspectives 
from the traditional point of view of agency problems to more complex ones over issues of ethics, accountability, transparency, and disclosures (Gill, 2008). The implementation of good corporate governance will be able to maintain a balance between achieving economic goals and social goals in the context of the company's sustainability in the future.

The results of this study found that the CSRxCG variable as an interaction between CSR and corporate governance variables has a negative and not significant direction in moderating the relationship of CSR to the dependent variable. In other words, corporate governance variable does not affect the relationship between CSR and corporate tax aggressiveness. The results of this study are consistent with the research conducted by Rashid (2018) who found that there was no relationship between corporate governance and CSR performance in 101 publicly listed companies in Bangladesh. Rashid (2018) argues that companies consider CSR impacts can be felt by stakeholders from the CSR performance carried out so that the companies do not consider it necessary to disclose them in the annual reports as part of the corporate governance mechanism.

\section{Conclusion}

This study aims to prove the impacts of both corporate social responsibility and corporate governance on corporate tax aggressiveness. The study is conducted using a fixed-effect model approach on the companies listed on the Indonesia Stock Exchange from 2014 to 2017. This research is conducted on 51 companies selected as samples using purposive sampling method. Based on the results of statistical tests, there are several things that can be concluded:

1. Corporate social responsibility (CSR) has a positive and significant effect on corporate tax aggressiveness. This study shows that the higher the CSR performance, the higher the tax aggressiveness. This can happen because companies consider CSR to be an additional burden that must be dealt with the company so that the company will tend to be more aggressive in tax planning.

2. Corporate governance has no effect on corporate tax aggressiveness. In other words, the levels of corporate governance implementation do not affect the practice of tax avoidance. This study also finds that public companies in Indonesia have not fully implemented good corporate governance even though there are rules that require public companies to implement GCG and disclose it in the company's annual reports. In addition, this study also finds that the companies that are indicated of tax avoidance practices have an average implementation of corporate governance which is both low in the aspect of equitable treatment of shareholders and the role of stakeholders based on the OECD Corporate Governance Implementation Guidelines.

3. Corporate governance has no effect in moderating the relationship of CSR to corporate tax aggressiveness. There is a possibility that the company does not view CSR disclosures as part of the corporate governance mechanism. Thus, no matter how good the implementation of corporate governance is, it will not affect the company's CSR performance. In other words, corporate governance will not affect the relationship between CSR and corporate tax aggressiveness.

\section{References}

Astra International. (2019). Social contributions overview. Astra.co.id. Retrieved from https://www.astra.co.id/CSR/Overview. [Accessed, January 25, 2019].

Avi-Yonah, R. S. (2008). Corporate social responsibility and strategic tax behavior. Tax and corporate governance (pp. 183-198). Berlin, Heidelberg: Springer.

Chen, S., Chen, X., Cheng, Q., \& Shevlin, T. (2010). Are family firms more tax aggressive than non-family firms? Journal of Financial Economics, 95(1), 41-61.

Cheung, Y.-L., Connelly, J. T., Estanislao, J. P., Limpaphayom, P., Lu, T., \& Utama, S. (2014). Corporate governance and firm valuation in Asian emerging markets. Corporate Governance in Emerging Markets (pp. 27-53). Berlin, Heidelberg: Springer.

Desai, M. A., \& Dharmapala, D. (2006). Corporate tax avoidance and high-powered incentives. Journal of Financial Economics, 79(1), 145-179.

Financial Services Authority Regulation. (2015). Financial Services Authority Regulation Number 21/POJK.04. Concerning the implementation of public company governance guidelines.

Frank, M. M., Lynch, L. J., \& Rego, S. O. (2009). Tax reporting aggressiveness and its relation to aggressive financial reporting. The Accounting Review, 84(2), 467-496.

Geraldina, I. (2013). Preference for accrual profit management or real profit management in tax shelter activities. Indonesian Journal of Accounting and Finance, 10(2), 206 - 224.

Ghozali, I. (2016). Multivariate analysis application with IBM SPSS 23 program. Semarang: Diponegoro University Publishing Agency.

Ghozali, I., \& Ratmono, D. (2013). Multivariate analysis and econometrics: Theory, concepts, and applications with eviews 8. Semarang: Diponegoro University Publishing Agency.

Gill, A. (2008). Corporate governance as social responsibility: A research agenda. Berkeley Journal of International Law, 26(2), 452-478.

Global Reporting Initiative. (2016). The consolidated series of GRI 2016 sustainability reporting standards. Amsterdam: GRI. 
Godfrey, J., Hodgson, A., Tarca, A., Hamilton, J., \& Holmes, S. (2010). Accounting theory (7th ed.). Australia: John Wiley \& Sons Australia, Ltd.

Gujarati, D. N., \& Porter, D. C. (2009). Basic econometrics (5th ed.). New York: McGraw Hill.

Gupta, S., \& Newberry, K. (1997). Determinants of the variability on corporate effective tax rates: Evidence from longitudinal data. Journal of Accounting and Public Policy, 16(1), 1-34.

Handajani, L., Subroto, B., \& Saraswati, E. (2014). Disclosure of corporate social responsibility: Determinants and consequences. Paper presented at the National Symposium on Accounting XVII Lombok. Indonesian Accounting Association Compartment Educator Accountants.

Hoechle, D. (2007). Robust standard errors for panel regressions with cross-sectional dependence. The Stata Journal, 7(3), 281-312.

Hung, M., Shi, J., \& Wang, Y. (2013). The effect of mandatory CSR disclosure on information asymmetry: Evidence from a quasinatural experiment in China. Paper presented at the Asian Finance Association (AsFA) 2013 Conference.

Irawan, H. P., \& Farahmita, A. (2013). Effects of management compensation and corporate governance on corporate tax management. Paper presented at the National Symposium on Accounting XVI Manado. Indonesian Accounting Association Compartment Educator Accountants.

Lanis, R., \& Richardson, G. (2012). Corporate social responsibility and tax aggressiveness : An empirical analysis. Journal of Accounting and Public Policy, 31(1), 86-108.

Mao, C. W. (2019). Effect of corporate social responsibility on corporate tax avoidance: Evidence from a matching approach. Quality \& Quantity, 53(1), 49-67. Available at: https://doi.org/10.1007/s11135-018-0722-9.

Maraya, A. D., \& Yendrawati, R. (2016). Effects of corporate governance and corporate social responsibility disclosure on tax avoidance: Empirical study on mining companies and CPO. Indonesian Journal of Accounting \& Auditing, 20(2), $147-159$.

Margolis, J. D., Elfenbein, H. A., \& Walsh, J. P. (2007). Does it pay to be good? A meta-analysis and redirection of research on the relationship between corporate social and financial performance. Ann Arbor, 1001, 48109-41234.

Minister of Finance Regulation Number. (2011). Minister of Finance Regulation Number 76 / PMK.03. Concerning procedures for recording and reporting national disaster management donations, research and development donations, Donations of Educational Facilities, Sports Development Donations, and Social Infrastructure Development Costs That Can Be Deducted from Gross Income.

Minor, D. B., \& Morgan, J. (2011). CSR as reputation insurance: Primum non nocere. California Management Reviewe, 53(3), $40-59$.

Pradipta, D. H., \& Supriyadi. (2015). Effect of corporate social responsibility (CSR), profitability, leverage, and independent commissioners on tax avoidance practices. Yogyakarta: Gadjah Mada University.

Rashid, A. (2018). The influence of corporate governance practices on corporate social responsibility reporting. Social Responsibility Journal, 14(1), 20-39.

Roman, L., \& Grant, R. (2014). Is corporate social responsibility performance associated with tax avoidance. Journal of Business Ethics, 127(2), 439-457.

Sari, D. K. (2010). Characteristics of company ownership, corporate governance, and aggressive tax measures. Thesis. Accounting Program, Faculty of Economics, University of Indonesia.

Schön, W. (2008). Tax and corporate governance: A legal approach. In: Schön W. (eds) Tax and Corporate Governance. MPI Studies on Intellectual Property, Competition and Tax Law (Vol. 3). Berlin, Heidelberg: Springer.

Sekaran, U. (2003). Research methods for business: A skill building approach. New York: John Willey \& Sons.

Sheikh, S., \& Rees, W. (1995). Corporate governance and corporate control. London: Cavendish Publishing Limited.

Slemrod, J. (2004). Cheating ourselves: The economics of tax evasion. Journal of Economic Perspectives, 21(1), 25-48.

Sugiyono. (2016). Business research methods (Quantitative, Qualitative and $R$ \& D Approaches). Bandung: Alfabeta.

Tjondro, E., Widuri, R., \& Katopo, J. M. (2016). Quality of corporate social responsibility and tax avoidance with profit performance as moderator. Journal of Accounting and Finance, 18(2), 105-118.

Uwuigbe, U. N., Egbide, B., \& Ayokunle, A. K. (2011). The effect of board size and board composition on firms corporate environmental disclosure: A study of selected firms in Nigeria. University of Pecs, 7(5), 164-176. 